\title{
MOTIVATION OF STUDENTS FOR INDEPENDENT WORK DURING TRAINING ACTIVITIES
}

\section{МОТИВАЦІЯ УЧНІВ ДО САМОСТІЙНОЇ РОБОТИ ПІД ЧАС НАВЧАЛЬНОї ДІЯЛЬНОСТІ}

\begin{abstract}
In order to formulate motivation in the selection and use of funds, it is necessary to possess not only the methodology for their application, but also knowledge of the learning conditions, age characteristics of students. Teachers should keep in mind that although the motivational sphere of the student's educational activity is characterized by a large set of motives, the following groups can be determined in the organization of effective independent work. Motivation is an issue worthy of investigation because it seems implicated in how successful language learners are. That's why most teachers and researchers have widely accepted motivation as one of the key factors which influence the rate and success of second/ foreign language learning. Motivation determines the extent of active, personal involvement in L2 learning. Without sufficient motivation, even individuals with the most remarkable abilities cannot accomplish long-term goals, and neither are appropriate curricula and good teaching enough on their own to ensure students achievement. So in this paper we tried to reveal the importance of motivation in foreign language acquisition.

The current article discusses the question of motivation of university students for independent work, which is done during training activities. Different theories and viewpoints of specialists to the investigated matter have been included in the discussions. "Maslows" Hierarchy of Needs Theory (1954), McClelland's Needs Theory (1961), and "Herzberg's Two-Factor Theory" are analyzed here. Some groups of motives are determined in the organization of effective independent work, such as social motives, cognitive motives and reaction to a number of external factors organizing educational activities. A number of suggestions are given to develop motivation of students in foreign language lessons.

Key words: motivation, independent work
\end{abstract} intrinsic motivation, extrinsic motivation, theory.
Щоб сфрормулювати мотивацію в учнів, необхідно володіти не тільки методологією ї̈ застосування, а й знаннями умов навчання, вікових особливостей учнів. Учителі повинні пам'ятати, що, хоча мотиваційна сорера навчальної діяльності студента характеризується великим набором мотивів, в організації есрективної самостійної роботи можна визначити такі групи. Мотивація че питання, яке заслуговує на дослідження, оскільки воно пов'язане з тим, наскільки успішним є вивчення мови. Ось чому більшість викладачів і дослідників широко прийняли мотивацію як один із ключових фракторів, що впливає на швидкість та успішність вивчення другої/іноземної мови. Мотивація визначає ступінь активної, особистої участі в навчанні L2. Без достатньої мотиваціі навіть люди з найвидатнішими здібностями не можуть досягти довготермінових цілей, а також відповідні навчальні програми та належне викладання не є достатніми, щоб забезпечити досягнення учнів. Тож у робот ми спробували розкрити важливість мотивації в оволодінні іноземною мовою.

У статті розглядається питання мотивації студентів університету до самостійної роботи, яка виконується під час навчальної діяльності. В обговорення включені різні теорії й точки зору фрахівців на досліджуване питання. Аналізуються теорія ієрархії потреб Маслоу (1954), теорія потреб Макклелланда (1961) і двофакторна теорія Герцберга. Деякі групи мотивів визнача ються в організації есрективної самостійної роботи, такі як соціальні мотиви, пізнавальні мотиви та реакція на низку зовнішніх фокторів, що організують навчальну діяльність. Подано низку пропозицій щодо розвитку мотивації учнів на уроках іноземної мови. Ключові слова: мотивація, самостійна робота, внутрішня мотивація, зовнішня мотивація, теорія.
Introduction. One of the important factors in organizing students' independent work is the motivation for learning. The problem of motivated independent activity in learning is not new. This is mainly due to the fact that the course on active independent work of a student becomes the basis for student preparation.

Independent work has an impact on the formation of the personality of a future specialist. In didactics, independence is also considered as an important personal quality and as a system of self-organization. Independent work provides the opportunity for students to carry out cognitive activities in learning.

\section{Methodology}

To investigate the current topic, some methods are considered to be appropriate. The main one is the method of observation. To follow the achievements and improvement of independent work, some groups of students and their lessons have been observed.
Besides, the linguistic analysis method is also used to analyze the material on this field.

\section{Theoretical underpinning}

What is motivation? Motivation is probably the most important factor that educators can target in order to improve learning.

According to Williams [11], the five key ingredients impacting student motivation are: student, teacher, content, method/process, and environment. Motivation is defined as the act or process of motivating; the condition of being motivating; a motivating force, stimulus, or influence; incentive; drive; something (such as a need or desire) that causes a person or student to act (Merriam-Webster, 1997); and the expenditure of effort to accomplish results [11].

Palmer reviews the "student motivation as an essential element that is necessary for quality education. In the late $1987 \mathrm{~s}$, according to Brophy motiva- 
tion to learn is a competence acquired "through general experience but stimulated most directly through modeling, communication of expectations, and direct instruction or socialization by significant others (especially parents and teachers)" [5; 7], offers some definition for motivation where, Cherry views motivation as "the process that initiates, guides and maintains goal oriented behaviours".

Brennen, believes motivation to be "... the level of effort an individual is willing to expend toward the achievement of a certain goal" Guay et al. [2, p. 712] describes it simply as "reasons underlying behaviour" [7].

Some authors support that, the student must have access, ability, interest, and value education. The teacher must be well trained, must focus and monitor the educational process, be dedicated and responsive to his or her students, and be inspirational. The content must be accurate, timely, stimulating, and pertinent to the student's current and future needs. The method or process must be inventive, encouraging, interesting, beneficial, and provide tools that can be applied to the student's real life. The environment needs to be accessible, safe, positive, personalized as much as possible, and empowering.

According to Palmer (2007), "Motivation is optimized when students are exposed to a large number of these motivating experiences and variables on a regular basis. That is, students ideally should have many sources of motivation in their learning experience in each class" [11].

Many theories have been postulated to explain motivation: "Maslows' Hierarchy of Needs Theory (1954), McClelland's Needs Theory (1961), and "Herzberg's Two-Factor Theory" [8].

Abraham Maslow's theory identifies five levels of hierarchical needs that every individual attempts to accomplish or conquer throughout one's life. The needs start with the physiological (hunger, thirst, shelter) and then move upward in a pyramid shape through safety, social, and esteem needs, to the ultimate need for self-actualization. His final need for self-actualization is defined as one's desire and striving towards maximum personal potential. The pyramid shape to the theory is intended to show that some needs are more important that others and must be satisfied before the other needs can serve as motivators.

McClelland's Need Theory explores the idea that there are three major "needs" that one will acquire over their lifetime as a result of the experiences in their careers or in their own personal lives. David I. McClelland believed that in order to understand human behavior and how an individual can be motivated, you must first understand their needs and inclinations. The Need for Achievement encompasses the desire to do better, to solve problems, and to master complex tasks. The Need for Affiliation is the desire for friendly and warm relations with others. These are often those passive individuals that try to avoid conflict at all times, even when it might be necessary to fulfill a task. Finally, the Need for Power is the desire to control others and influence their behavior [8].

According to Rily, Herzberg's Two-Factor Theory divides motivation and job satisfaction into two groups of factors known as the motivation factors and hygiene factors. According to Frederick Herzberg, the motivating factors are the six job content' factors that include achievement, recognition, work itself, responsibility, advancement, and possibility of growth. Hygiene factors are the 'job context' factors, which include company policy, supervision, relationship with supervision, work conditions, relationship with peers, salary, personal life, relationship with subordinates, status, and job security" [8].

According to Taylor, the root word of the term motivation is movere (to move). In regards to learning, motivation generally involves inner forces, enduring traits, behavioral responses to stimuli, and sets of beliefs and affects. She said that the study of motivation can be broken down into two main categories: behavioral and cognitive theories. Behavioral theories "view motivation as a change in the rate, frequency of occurrence, or form of behavior as a function of environmental events and stimuli". Teachers can shape student responses by conditioning the external environment. In contrast, cognitive theories stress the internal structures and processing of information and beliefs. Cognitive theories stress the importance of perceptions of competence, values, affects, goals, and social comparisons when measuring motivation [9].

By analyzing the ideas of different scholars about motivation, we can express our opinion as follows: Although some scholars describe and analyze motivation from different perspectives, one idea remains the same: that motivation plays a major role in students' independent work in the learning process.

\section{Discussion}

In order to formulate motivation in the selection and use of funds, it is necessary to possess not only the methodology for their application, but also knowledge of the learning conditions, age characteristics of students. Independent work motivates students to study provided that a number of didactic requirements are clearly fulfilled: firstly, the teacher's understanding of the essence of students 'independent work, knowledge of the existing classifications of independent work, didactic goals and methodological tasks to be solved within the framework of one or another kind. Secondly, the stages of students' inclusion in independent activity should be built taking into account their individual experience (knowledge, abilities, skills). Thirdly, it is necessary to take into consideration the leading function of the teacher in this process.

In this regard, two stages can be distinguished. At the first stage, the assimilation of some information and the mastery of the methods of obtaining it in 
a particular area is carried out with the participation of the teacher in the educational activities of students.

At the second stage of self-organization, the indirect control actions of the teacher, monitoring the students' activities, its control, and correction are appropriate. This is the period of independent work. It should be noted that the student's motivational sphere is characterized by a large set of motives.

Motivation as a system of motives performs several functions: it stimulates directs and organizes behavior, gives it personal meaning and significance.

Teachers should keep in mind that although the motivational sphere of the student's educational activity is characterized by a large set of motives, the following groups can be determined in the organization of effective independent work:

1. Social motives (students' deep awareness of their life needs, a desire to benefit society, an understanding of the need for knowledge in terms of training themselves as a specialist); The development of the motives of this group in the process of independent work is possible by turning them from understandable into effective ones by showing the applied nature and professional orientation of the course being studied.

2. Cognitive motives associated with a developed cognitive interest in the academic discipline and science that it represents; in the process of independent work, the teacher can develop the motives of this group, forming students' ideas about knowledge.

3. Reaction to a number of external factors that organize educational activities; the influence of these motives on the learning outcome directly depends on the integrity of the planning of activities for the implementation of the independent work system (clarity of their programs, consultations, assessments) and a number of internal incentives (the need for scholarships, prestige, etc.).

\section{Implication to Research and Practice}

Many authors dealing with the motivation of students in performing independent work distinguish two types of motivation: Intrinsic and extrinsic motivation: Individuals who are motivated intrinsically tend to develop high regard for learning course information without the use of external rewards or reinforcement. On the other hand, individuals who are motivated extrinsically rely solely on rewards and desirable results for their motivation.

Intrinsic motivation is doing something for the sake of personal satisfaction. The primary motivator is internal (i.e. you don't expect to get anything in return). You are intrinsically motivated when you do something simply because it makes you feel good, is personally challenging, and/or leads to a sense of accomplishment. For example, students may be intrinsically motivated to read because it satisfies their curiosity about the world and brings them a sense of calm. Intrinsic motivation is doing something "just because."
Extrinsic motivation is doing something to earn a reward or to avoid a punishment. The primary motivator is external (i.e. you expect to get something for completing a certain task, or you want to avoid a consequence for not doing something). For example, a student studies for a test because they want to earn a good grade. Or they mind their behavior because they don't want to lose their recess. Students choose behaviors not because they enjoy them or find them satisfying, but in order to get something in return or avoid an adverse outcome.

According to Leila Anjomshoa and Firooz Sadighi intrinsic/extrinsic motivation refers to whether the motivation is more inside a person or outside of him/ her. Intrinsic motivation refers to the motivation which is originated inside a person. There is no reward except the activity itself. It means that the essence of motivated action that is, sense of autonomy and the desire is self-initiating and self-regulating while in extrinsic motivation there is an anticipation of reward from outside and a person is motivated from an outside source rather than the self [1]. Extrinsically motivated behaviors are carried out to get a reward from outside and beyond the self. Maslow believed that intrinsic motivation is noticeably superior to extrinsic because we are motivated to achieve "self-actualization". Bruner [2] claimed that one of the most effective ways to help students is to free them from the control of rewards. In some cases, the two kinds of motivation may overlap to some degree because one may be motivated from both an inside source and an outside one at the same time. Generally speaking, both kinds of motivation play important roles in learning and lack of motivation can cause procrastination because motivation is the driving force that makes people act. In other words, presence of motivation can increase learning behavior. Teachers need to know the type of motivation and its sources to meet the students' particular needs.

Intrinsic motivation is motivation that is animated by personal enjoyment, interest, or pleasure. As Deci et al. [3] observe, "intrinsic motivation energizes and sustains activities through the spontaneous satisfactions inherent in effective volitional action. It is manifest in behaviors such as play, exploration, and challenge seeking that people often do for external rewards".

"Extrinsic motivators primarily have been understood within a behaviorist framework. Specific stimuli external to the self (e.g., social expectations, rewards, praise, punishments, threats, risks) are believed to produce specific predictable outcomes" [10].

The word intrinsic means to come from inside, so it seems counterintuitive to imply that we can train a student to be intrinsically motivated. While we cannot change who a student is as an individual, we can create the optimum environment to encourage students to develop their own motivation muscles. Here are a few suggestions to get you started. 
1. Know your students.

Get to know your students as individuals and discover what they're interested in and how they learn best. Then design your instruction around these motivating factors. Change up your instruction to keep the students engaged and interested. Provide a mix of independent, partner, and group work. Use technology. Incorporate art. Keep your finger on the pulse of your students and adjust as necessary.

2. Give them ownership of their environment.

Involve your students in creating the guiding principles of your classroom community. Work together to establish the optimal learning environment for that particular group of individuals. Like all humans, your students are more likely to take care of something they helped to create.

3. Make sure they have a solid foundation.

Explicitly teach basic skills so that students have a solid foundation of knowledge to build upon. Intrinsic motivation will come from being able to tackle complex tasks. Build up students' confidence and make sure they have the resources they need before they begin.

\section{Practice setting goals.}

Tap into the power of setting goals with-not foryour students. According to literacy consultant Lindsey Barrett, "Research spanning decades shows that setting student goals improves both motivation and achievement, encourages a growth mindset, and also supports the development of skills students need to be prepared for their future careers."

5. Give specific feedback.

Give students feedback that focuses on their strengths instead of their weaknesses and be as specific as you possibly can. Instead of saying "great job!" or "you're so smart," tie your comments directly to the student's effort. For example, "Your essay turned out so well because you created an excellent outline to work from", or "Your conclusion from the science lab was so insightful because you made very keen observations".

6. Tap into their innate curiosity.

Encourage students to take on assignments simply because they want to know more, instead of feeling required to do so just to receive a grade. Establish a Genius Hour as part of your curriculum to give students the opportunity to direct their own learning.

7. As much as possible, allow students choice in their work.

In his book The Highly Engaged Classroom, Dr. Robert Marzano touts the importance of student choice. He states that when students are given choices, they perceive classroom activities as more important. This increases their intrinsic motivation for putting in effort and going deeper with their learning.

8. Make the connection between classroom activities and real-world situations.

Maybe one of your students wants to be an engineer when they grow up. If so, they need to have a solid understanding of math concepts. Knowing that what they're studying will help them meet their goals in the future will boost your students' intrinsic motivation.

9. Get out of the way.

Trust your students to find their own way as often as possible. Your work as a teacher is to lay the groundwork and provide a framework for the work to be done. Michael Linsin shares this gentle but powerful way to increase students' learning, motivation and independence: "Prepare them for success with spoton instruction, to be sure", he advises. "But then fade into the background. Independent practice is critical to learning, and offering too much help is often more problematic than not giving enough".

Thus, both aspects of motivation play an important role in students' independent work. They complement each other and contribute to students' foreign language learning.

Conclusion. Motivation is an issue worthy of investigation because it seems implicated in how successful language learners are. That's why most teachers and researchers have widely accepted motivation as one of the key factors which influence the rate and success of second/foreign language learning. Motivation determines the extent of active, personal involvement in L2 learning. Without sufficient motivation, even individuals with the most remarkable abilities cannot accomplish longterm goals, and neither are appropriate curricula and good teaching enough on their own to ensure students achievement. So in this paper we tried to reveal the importance of motivation in foreign language acquisition.

Analyzing motivation, its types, its role and importance we came to the conclusion that lack of motivation in education could damage the learning process of students. Creating motivation for independent work of students helps them not only in their studies but also in their socio-cultural lives.

\section{REFERENCES:}

1. Anjomshoa Leila \& Sadighi Firooz (2015). The Importance of Motivation in Second Language Acquisition International Journal on Studies in English Language and Literature (IJSELL) Volume 3, Issue 2, February PP 126-137 ISSN 2347-3126 (Print) \& ISSN 2347-3134 (Online) www.arcjournals.org.

2. Chalak A. \& Kassaian Z (2010). Motivation And Attitudes Of Iranian Undergraduate EFL Students Towards Learning English. GEMA Online ${ }^{\mathrm{TM}}$ Journal of Language Studies 37 Volume 10(2)2010.

3. Deci E.L., Vallerand R.J., Pelletier L.G., Ryan R.M. (1991). Motivation and Education: The self - Determination Perspective. Educational Psychologist, 26 (384), 325-246.

4. Gardner R.C. (1985). The Attitude/Motivation Test Battery: Technical Report.

5. Gregory R.W. (2009). Student Motivation. [PDF document]. Retrieved from Lecture Notes Online Web site: www.westpoint.edu/cfe. 
6. Maslow A. (1970). Motivation and personality. New York: Harper and Row. xxx, 369 pages. Interest level: academic.

7. Nukpe P. (2012). Motivation: theory and use in Higher Education. Investigtions in university teaching and learning, (8), 1-2.

8. Riley Sh. (2005). "Herzberg's Two-Factor Theory of Motivation Applied to the Motivational Techniques within Financial Institutions". Senior Honors Theses p. 3-4. Retriveved from : http://commons.emich.edu/honors.
9. Taylor W. (2012). Studying \& Understanding Motivation [PDF document]. Retrieved from Lecture Notes Online Web site: www.westpoint.edu/cfe.

10. Toshalis E. \& Nakkula M.J. (2012). Motivation, Engagenment and Student Voice. The student at the Center Series. Retrieved from www.howyoulearn.org.

11. Williams K. \& Williams C. (2011). Five key ingredients for improving motivation. Research in Higher Education Journal, 11. URL: http://aabri.com/manuscripts/ 11834.pdf. 